\title{
How Prepared Are You For The First Day Of Class--Or "Blink", Does It Matter?
}

William Young Davis, (Email:wydavis@email.uncc.edu), University of North Carolina, Charlotte Michael E. Waggy, (Email:mewaggy@email.uncc.edu), University of North Carolina, Charlotte

\begin{abstract}
Recent findings indicate that students often form lasting impressions and opinions of teachers and their potential teaching effectiveness within the first few minutes or even the first few seconds on the first day of class. This paper argues it is the entire first day of an economics class that deserves special attention. Teachers of economics should clearly define economics as a science and explain its scientific methodology. They should emphasize the distinct limitations of economics that explain the many widespread disagreements among economists. Of equal importance, they should stress that understanding the science of economics will be of assistance in preparing and expanding a student's critical-thinking skills that will ultimately result in sound decisions throughout life. Finally, the paper calls upon teachers to bond with their students by reaching out with genuine concern for each student's success in the class.
\end{abstract}

\section{INTRODUCTION}

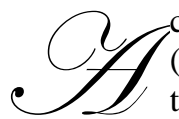

ccording to the bestseller, Blink by Gladwell (2005), and an article by Ambady, Nalini, and Rosenthal (1993), students formulate enduring opinions within a few seconds or minutes of observing a teacher for the first time. While this notion may or may not be accurate, students do formulate opinions of teachers on the first day of class. Additionally, the first day of class establishes a "contract" between the students and teachers for the upcoming term in the form of a syllabus. ${ }^{1}$ Students form expectations of their interest in the subject of economics, the workload requirements, and the level of difficulty. Teachers should address these expectations of students. Thus, the first day of class is probably the most important day of the term.

The purpose of this paper is to propose a list of topics that should be covered on the first day of any principles of economics class, micro or macro. These topics should be readdressed and reinforced throughout the term in each major topic area. First, the paper calls for a rigorous definition of economics, with emphasis on its methodology as a science. Second, it proposes that the limitations of economics be clearly stated. Third, it suggests that students be made aware of why there is widespread disagreement among economists over policy issues. Fourth, the paper describes the importance of teaching students the economic way of thinking to assist them in developing critical-thinking skills that will benefit them in the multitude of decisions that they will face in their personal and professional lives. Finally, it calls for teachers to establish a rapport with their students by humanizing themselves and expressing genuine concern for each student's success.

\section{THE SCIENCE OF ECONOMICS AND ITS METHODOLOGY}

Economists define themselves as social scientists, yet often lose sight of the definition of science which is a "body of facts" Students should be forewarned that a body of facts has no opinion; and is therefore policy neutral.

In a random selection of fourteen principles of economics textbooks, ${ }^{2}$ six do not mention the term "science" when defining or discussing the basic methodology of economics. Four of the texts mention that economics is a social science, but do not use the term science in the definition of economics, nor do they discuss why economics is a science, or the methodology of the scientific method. Thus, ten of these fourteen texts do not include science in their definitions of economics. Three of the fourteen texts include the term science in their definition of economics, but do 
not elaborate on the meaning of the term science. Only one text of the fourteen discusses the scientific methodology of economics.

Two examples illustrate the above points. The Micro Economy Today, 10th Edition, 2006, Schiller (2006) refers to "The science of economics...," but without any explanation of science or why economics is a science. This text goes on to define economics as "The study of how best to allocate scarce resources among competing uses." Schiller's treatment of economics as a science is typical of the texts that mention the word science, as a "check-thescience-box" formality. An exception is Economics: Private and Public Choice, 11th Edition, Gwartney, Stroup, Sobel, Macpherson (2006). This book defines "scientific thinking," and briefly explains it.

How does the scientific method employed by economists tackle cause/effect relationships? Unlike natural scientists, who in many cases are able to perform carefully-controlled experiments, economists must primarily rely on ceteris paribus assumptions to simulate the scientific search for cause/effect. ${ }^{3}$ Nonetheless, given our limitations, economists are no less concerned with determining factual, non-biased laws, theories, and hypotheses than natural scientists. This point is critical, but rarely, elucidated in principles textbooks.

Universities have traditionally established general degree requirements that include from one to three courses in the life or natural sciences for the express purpose of students learning the scientific method. The goal of these course requirements is not to educate physicists or biologists, but to teach students the scientific method. Few, if any general degree requirements are required of students to understand the scientific nature of the social sciences, including economics. Yet students will need the scientific method as employed in the social sciences in the world they face, far more than the controlled experiments in, for example, physics.

Positive versus normative economics is treated in a cursory "check-the-box fashion" in virtually all texts surveyed. However, as will be discussed below, this distinction is essential to understanding the world of economics.

\section{LIMITATIONS OF THE SCIENCE OF ECONOMICS}

The science of economics is restricted by "David Hume's Dictum," as noted by Landreth and Colander (1994): one cannot draw "...an ethical implication from a nonethical analysis." As a result, economics, as with all sciences, offers no specific answers to any policy question. Economics can only state scientifically the projected costs and benefits of alternative policy options, but economics itself is "policy neutral." The incorrect definition of economics by Schiller (2006) in his textbook cited above illustrates this point. Economics is not "the study of how best [italics added] to allocate scarce resources...." Any "appropriate" policy is always based on normative considerations, i.e., value judgments, and at least indirectly, interpersonal comparisons of utility functions.

Economists by their education and training possess no authority or expertise to favor or recommend one policy alternative over another. Virtually all, if not all, policy decisions involve tradeoffs. Invariably one group benefits, while another group bears costs. Consequently, policy recommendations involve "ethical" considerations and/or value judgments of who should be advantaged versus who should be disadvantaged.

Yet, economists teach normative policy prescriptions based on implicit value judgments throughout micro and macro economic principles. They do so without acknowledging the unstated foundations for their policy prescriptions, i.e. opinions. The real sources of policy prescriptions are inscrutable to students, who tend to confuse the science of economics with the value-laden opinions of economists.

In addition to Shiller's ill-defined definition of economics, numerous other examples are common. These include, but are not limited to, policy implications with respect to the following areas:

1. The production-possibilities curve and economic efficiency

2. Government mandated prices above equilibrium price (price floors), and below equilibrium price (price ceilings)

3. International trade

4. External costs 
The first model in most, if not all, economics texts is the production-possibilities curve. Areas within the frontier of the curve are dismissed as inefficient, and at least by implication, undesirable. Is efficiency always a desirable goal and inefficiency always an undesirable goal? Points inside the production-possibilities curve represent unemployment rates above the natural rate of unemployment. Yet, from the point of view of employed consumers, high unemployment rates and a slack labor market may be desirable. Anyone needing a plumber or electrician in a tight labor market would welcome higher unemployment among plumbers and electricians. On the other hand, high unemployment rates are not desirable from the point of view of workers, particularly the unemployed. The science of economics does not indicate the "desirability" or the "optimal level" of any level of efficiency or unemployment. The following example illustrates this point.

The average number of paid holidays per year in the U.S. is approximately 12 per year; in Western European countries, the number paid holidays annually is much higher: Britain, 28 days; Germany, 35 days; France, 37 days; and Italy, 45 days (Sloan \& Witney, 2007). The average worker in Western European countries receives 6 weeks of legally-mandated paid vacation a year, and is prohibited from seeking alternative employment during the vacation period(s). In the U.S. the average number of paid vacation days is much lower. Again, the science of economics cannot judge the correct or optimal number of paid holidays or paid vacation days. ${ }^{4}$

Example two is the interpretation of equilibrium price in supply and demand models. All principles of economics students learn that supply and demand analysis is scientific: when price is legally established above equilibrium, a surplus results; when price is legally established below equilibrium, a shortage results. Do these shortages and surpluses scientifically demonstrate that the equilibrium, market-clearing price is optimal or desirable? Economics does not provide an answer: price controls above or below the equilibrium price, which are not uncommon in society, favor certain groups and disfavor other groups. Rent controls favor existing renters, at least in the short run, and disfavor would-be renters facing a shortage of apartments.

Similarly, minimum wage laws establish wages for unskilled workers above the equilibrium wage. Those workers benefiting from these laws are benefited; unskilled workers who lose their jobs suffer from minimum wage laws. Economics cannot scientifically state that the equilibrium wage is preferred over a legally-mandated minimum wage or vice versa. Yet many textbooks overtly, or certainly by implication, criticize minimum wage laws as "unjust" to the workers unemployed by theses laws. Economists are implicitly making policy prescriptions on the basis of interpersonal utility functions. Many workers are helped, a few are hurt; therefore, minimum wages are a "bad" policy. In reality, the science of economics has no opinion on the desirability or non-desirability of minimum wages.

A third example is international trade. Following the Law of Comparative Advantage, nations will increase their total output and consumption levels; therefore, free trade is "good." And while the standard of living of the many will be enhanced; the livelihood of a few will be ended.

Economic texts generally bless, directly or indirectly, international trade even though the underlying reasoning is the opposite of that in the case of minimum wage legislation discussed above: minimum wage laws are given a "red light" because the cost is "too" high for the resulting unemployed workers, even though many other workers will receive higher wages; international trade is given a "green light" because the cost of the few additional unemployed workers is not deemed important enough to offset the additional goods and services for the many. Nothing in economic theory or science justifies this distinction.

A fourth example relates to external costs. Even the generally held view by economists that when actions by one party impose external costs on a another party, corrective action by government is called for, cannot be justified by the science of economics. As Ronald Coase has argued, effective property rights allow all parties involved in external cost disputes to resolve the issue. Both the traditional view toward externalities and the Coase Theorem reflect value judgments, not science.

Economics does not provide any definitive answers to good/bad, right/wrong, or correct/incorrect. Whenever economists call for a specific policy, it is almost invariably based on the personal and political values of economists as 
opposed to the science of economics. This point should be emphasized to students from the first of class and throughout the semester.

\section{DISAGREEMENTS AMONG ECONOMISTS}

As is well known, if the world's economists were laid end to end, they could not reach a conclusion. As indicated above, the science of economics does not provide "correct" policy prescriptions. It is little wonder that economists virtually never offer a unified answer to a policy issue, but a plethora of answers. Each economist is left to reach conclusions regarding policy issues based on their individual values. Conservative economists generally oppose price controls that interfere with equilibrium prices, favor tax cuts for the well-to-do over the poor, and generally prefer a reduction in social welfare programs. Conversely, liberal economists would generally favor the opposite. Unfortunately, the views of economists are inconsistent on policy issues because they are based on value judgments, leaving both students and the general public to wonder if economists have any clear-cut answers at all. Economics is viewed as inscrutable! The answer is that the science of economics does not have answers to any policy issue.

To further confuse policy debates, there are numerous "think-tanks" that have political axes to grind. The purpose of these think tanks is not to generate scientific analysis, but rather to promote and support a political point of view. Virtually all of the "research" conducted by "in-house" economists is published in house because it does not meet the rigor of traditional academic publications. Examples abound of conservative think tanks: the American Enterprise Institute, the Heritage Foundation, the Cato Institute, the Hudson Institute, and the Hoover Institute, to name a few. The Brookings Institute would be categorized as moderate to slightly liberal. Principles of economics students should be made aware of the biased points of view of in-house economists employed by think tanks, and keep in mind that they have an agenda, not based on scientific economics, but individual values or political beliefs. While they may sincerely believe the policy positions of their think-tanks, they are, nonetheless, paid lobbyists.

It is incumbent that economists distinguish between positive and normative economics. This distinction should be emphasized from the first day of an economics until the last day of the class.

\section{APPLICATIONS OF THE SCIENCE OF ECONOMICS}

Despite the major differences among economists on policy issues, the science of economics does provide students with highly valuable tools for critical thinking and decision making. Principles texts should repeatedly emphasize and dwell on this aspect of economics. Problems at the end of chapters and test bank questions should reinforce this concept. The point should be made over and over that unless one understands the tradeoffs in any decision, it is impossible to act rationally or intelligently.

An example extremely important to any student is the choice of a college major. Obviously, not all majors are created equally. Whether or not this issue is discussed on the first day of class, it offers an excellent opportunity for the teacher of economics to provide students an example of items that will be learned in the course. What are the economic benefits and costs, i.e., tradeoffs, of major X versus major Y. Once the tradeoffs are determined, the ultimate answer, again, will depend on personal values and preferences. But the value of the economic way of thinking is that students will have rationally considered the appropriate tradeoffs between prospective majors.

Another example to be discussed on the first day, or promised for future discussion relates to changing majors. Once a major is selected by a student, should they stick with the major if they are performing poorly? In this instance, economics provides useful guidance. One scientific study found that students with four different majors posted the highest graduation rates. This finding is not surprising because struggling in the wrong major is a recipe for failure. Students should be taught the economic concept that sunk costs are sunk (Davis, 2005), and searching for the "right" major is intelligent behavior. Of course, searching for the right major is costly, and the appropriate amount of amount of searching is a judgment call. 


\section{BONDING WITH STUDENTS}

Perhaps the most important aspect of the first day of class relates to the interaction between student and teacher. It is easy for the teacher to perfunctorily list major classroom policies on the first day of class. But students expect more. Does a particular teacher demonstrate any concern for the success of students? When we visit a physician, we expect the doctor to show concern for our physical and / or mental health. Students, likewise, expect concern from teachers concerning their academic careers.

Teachers can generate a bond with students in many ways. An essential ingredient to this bonding is a genuine concern on the part of the teacher. Establishing genuine concern is not complicated. Truthful and sincere comments such as "I am here to help you;" "My office hours are for your assistance, please come by and see me if you have any questions or problems;" "I require attendance in order to help you succeed in this class;" "Not too long ago, I was where you are today, and I remember how it felt. If there is anything that I can do to help you, please ask;" "Feel free to interrupt my lecture if you have any questions whatsoever;" "I succeed as a teacher only if you succeed as a student. Let's work together and both succeed."

\section{SUMMARY}

This paper proposed a list of topics that should be covered on the first day of a principles of economics class, micro or macro. These topics should be readdressed and reinforced as the term progresses. First, the paper called for a definitive definition of economics, with emphasis on its methodology as a science. Second, it proposed that the limitations of economics be clearly stated: the science of economics does not provide answers to policy issues. Third, it suggested that students be made aware of why there is widespread disagreement among economists. Fourth, the paper described the importance of students applying economic concepts in their lives. Finally, it called for teachers to bond with their students by humanizing themselves and expressing genuine concern for the success of their students.

\section{REFERENCES}

1. Ambady, Nalini and Rosenthat, Robert, 1993, Half a Minute: Predicting Teacher Evaluations From Thin slices of Nonverbal Behavior and Physical Attractiveness, Journal of Personality and Social Psychology 4, (No. 3), pp. 431-441.

2. Ayers, Ronald and Collinge, Robert, 2002, Macroeconomics: Explore and Apply. Pearson Prentice-Hall.

3. Davis, William Young, 2005, Return the Sunk Costs Are Sunk Concept to Principles of Economics Textbooks, Journal of Business \& Economics Research 3, (No. 6), pp. 79-82.

4. Frank, Robert and Bernanke, Ben, 2004, Principles of Macroeconomics, Second Edition. Boston: McGrawHill Irwin.

5. Gladwell, Malcolm, 2005, Blink. New York: Little, Brown and Company.

6. Gwartney, James D., Stroup, Richard L., Sobel, Russell S., Macpherson, David A, 2006, Economics: Private \& Pubic Choice, 2006, Mason, Ohio: Thomson, South-Western.

7. Landreth, Harry \& Colander, David C., History of Economic Thought. Boston: Houghton Mifflin. p. 248.

8. Miller, Roger, 2003, Economics for Today: The Micro View, $12^{\text {th }}$ Edition. Pearson Addison-Wesley.

9. Parkin, Michael, 2003, Macroeconomics, Sixth Edition. Pearson Addison-Wesley.

10. Schiller, Bradley R., 2006, The Micro Economy Today. Boston: McGraw-Hill Irwin.

11. Sloan, Arthur and Witney, Fred, Labor Relations, Twelfth Edition. UpperSaddle River, New Jersey. Pearson/Prentice Hall, p. 318.

12. Tucker, Irvin, 2005, Economics for Today, Fourth Edition. Mason, Ohio. Thomson South-Western. 


\section{Appendix A}

\section{Information Content and Distribution of Course Syllabi}

Minimum Information Content for Syllabi - All syllabi for Belk College of Business courses require, at a minimum, the following information:

1. Course title.

2. Course abbreviation and number plus section number .

3. Current semester identification.

4. Instructor's name.

5. Office phone and email.

6. Office location (building and room number).

7. Office hours (see below for details).

8. Course description (must include, but not limited to, the Catalog description).

9. Course Objectives (must include, but not limited to, development of skills/core competencies identified by the college and/or the department for the course).

10. Course textbook(s) with a clear indication as to whether each is required or suggested.

11. Supplementary materials to be used .

12. Instructor's attendance policy.

13. A description of assignments to be evaluated.

14. Grade allocation across assignments.

15. A course schedule (ideally this should by broken into class periods, with textbook chapters and other assignments required for the period, and identification of any other topics critical to the class objectives or core curriculum).

16. A statement regarding academic integrity.

\section{Additional Considerations}

1. Drop Deadline The deadline date to withdraw from a course and retain other courses should be noted in the course schedule. Prior to this deadline faculty should attempt to schedule an assessment of student progress (such as a test, project, or paper) and report the results to students.

2. Office Hours The College Workload Policy (see point 8 of Section IV. Additional Workload Policy Considerations) requires that faculty members should maintain minimum weekly office hours of three hours, four hours, and five hours for the Research, Balanced and Teaching options, respectively. Part-time instructors teaching one, two, or three or more courses are expected to maintain minimum weekly office hours of two hours, four hours, or five hours, respectively.

The above hours are the minimum required weekly office hours. Sound pedagogy may require more than these stated minima: additional stated office hours or office hours 'by appointment' are encouraged.

All faculty members are expected to be in their offices available to meet with students during the office hours stated in the course syllabus. If an emergency requiring a faculty member to miss some/all of these posted office hours occurs, the faculty member should post a notice on her/his office door and inform the department secretary.

3. Adverse Weather Policies The University's Adverse Weather Policy (Policy Statement \#13) states that, without exceptions, the University is open unless the Chancellor (or Chancellor's delegate) announces that the University is closed. If the University remains open but you determine that observing the normal schedule would require hazardous to travel and act on this determination, you need to inform your Department Chairperson that you are canceling your classes and you need to schedule make-up classes to complete the interrupted activities. The University's inclement weather number is 704-786-Xxxx.

See Appendix A for a list of items included in syllabi at the Belk College of Business at the University of North Carolina at Charlotte.

2 Principles texts reviewed are listed in the Reference section of this paper.

3 Regression analysis and other statistical techniques attempt to consider, hold constant, the influences of other variables in the determination of cause/effect relationships.

4 The number of paid holidays and paid vacation in Western European countries are designed, in part, to support family values. Whether it is cause/effect or not, divorce rates in Western European countries are dramatically lower than those in the U.S. In one Western European country, the divorce rate is half that of the U.S. 